\section{$-$ \\ journal.phaselis.org \\ open 2 access journals}

Atıf Düzeni

\begin{abstract}
DOI: 10.18367/Pha.16006
\end{abstract}
Geliş Tarihi: 01.05.2016 | Kabul Tarihi: 28.05.2016 | Online Yayın Tarihi: 22.06.2016

PHASELIS: Disiplinlerarası Akdeniz Araştırmaları Dergisi'nde bulunan içeriklerin tümü kullanıcılara açık, serbestçe/ücretsiz "açık erişimli" bir dergidir. Kullanıcılar, yayıncıdan ve yazar(lar)dan izin almaksızın, dergideki makaleleri tam metin olarak okuyabilir, indirebilir, dağıtabilir, makalelerin çıktısını alabilir ve kaynak göstererek makalelere bağlantı verebilir.

PHASELIS: Disiplinlerarası Akdeniz Araştırmaları Dergisi uluslararası hakemli elektronik (online) bir dergi olup değerlendirme süreci biten makaleler derginin web sitesinde (journal.phaselis.org) yıl boyunca ilgili sayının içinde (Volume II: Ocak-Aralık 2016) yayımlanır. Aralık ayı sonunda ilgili yıla ait sayı tamamlanır.

Dergide yayımlanan eserlerin sorumluluğu yazarlarına aittir.

Editörya Phaselis Research Project

www.phaselis.org 


\title{
Phaselis Hidrografi Sistemine Dair Değerlendirmeler
}

\author{
An Assessment of the Hydrographical System of Phaselis
}

\author{
Mehmet KÜRKÇÜ*
}

Öz: Akdeniz'in doğusunda 3 adet limanıyla deniz ticaret yolları üzerinde önemli bir konuma sahip olan Phaselis kenti, Roma İmparatorluk Dönemi'nde Pax Romana'nın sağladığı ekonomik rahatık ve refah sonucu hamamlar, suyolları, anıtsal çeşmeler ve kapılar gibi imparatorluğu temsil eden yapılarla donatılmıştır.

Araştırma kapsamında kentteki bu yapılara su sağlayan Tahtalı Dağ doğu yamacı su kaynaklarının konumu, suyun Phaselis'e ulaştırılırken izlediği olası güzergâh, suyolunun (aquaeductus) mimari yapısı ve Roma Imparatorluk Dönemi'nde Akdeniz havzasında inşa edilen suyollarında uygulanan tekniklere yer verilmiştir. Phaselis'teki suyolunun 1029 metre yükseklikte yüzeye çıktığı Sıtma Pınarı mevki ile kent içerisinden kemerler üzerinde geçen bölümleri arasında, yak. 1020 metreye ulaşan bir kot farkı bulunmaktadır. Iki sektör arasındaki mesafe kuş uçuşu 8 kilometre olarak hesaplanmıştır. Bu özellikleriyle değerlendirildiğinde suyolunun bir takım teknik ve mimari önlemler alınmaksızın düz bir hat üzerinde kente ulaşmış olması mümkün görülmemektedir. Çalışmada Phaselis kenti suyolları ve hidrolik düzenlemeleri araştırmaları sürecinde tespit edilen arkeolojik bulgular da imparatorluğun diğer kentlerinde bulunan benzer örneklerle karşılaştırılarak analiz edilmiştir.

Anahtar sözcükler: Phaselis Suyolları · Enerji Kırıcılar · Roma Suyolları · Hidrografi · Roma İmparatorluk Dönemi

Abstract: Situated in the eastern Mediterranean on the sea trade routes, with its three sea ports the city of Phaselis was embellished through the many public buildings that represented the Roman Empire such as: baths, aqueducts, fountains and monumental gates during the Roman Imperial Era, a result of the economic prosperity and welfare consequent upon the Pax Romana.

The location of the fresh water resources on the east slope of the Tahtalı Mountain, that provided the flow of water to the public structures constructed in the city, the architectural design of the aqueducts and the techniques applied to the aqueducts constructed during the course of the Roman Imperial Era in the Mediterranean basin were held in the scope of this research. There is almost 1020 meters of difference in the altitude between the aqueducts that passes through the city and the SitmaPınarı location where the altitude of the aqueducts reaches to 1029 meters high. The bird's eye distance between those two places were measured as 8000 meters. Taking in to consideration this physical status, it seems impossible that the aqueduct reached to the city on a straight line without taking architectural measures. In the research the aqueducts of Phaselis and the archeological finds retained during investigation of hydraulic regulations have been compared and analyzed by the similar finds unearthed in the other cities of the Empire.

Keywords: Phaselis Water Supply · Steep Chutes · Roman Aqueducts · Hydrography · Roman Imperial Period

\footnotetext{
Dr., Université de Sorbonne, Paris IV. mhmtkurkcu@gmail.com
} 
Phaselis kenti suyolları ve hidrolik düzenlemelerine ilişkin araştırmalar "Phaselis Antik Kenti ve Teritoryumu Yüzey Araştırması” projesinin önemli bir bölümünü oluşturmaktadır. Çalışmanın amacı kent içerisinde ve hinterlandında yer alan hidrolik yapıları tespit etmek ve kayıt altına almak, içlerinden daha önceleri incelemelere konu olanların günümüzdeki durumlarını belirlemek, zaman içerisinde uğradıkları değişimleri saptamak ve buradan hareketle kent dokusundaki gelişmeleri ortaya çıkarmaktır.

Çalışma yöntemi olarak öncelikle kent ve çevresinde bizden önce konuya yönelik yapılan araştırma ve yayınlar taranmıştır ${ }^{1}$. Kent ve teritoryumunda 2014 ve 2015 yıllarında yapılan araştırmalar ışı̆̆ında daha önceden tespit edilen, belgelenen ve literatüre kazandırılan veriler değerlendirilmiş, Phaselis'e su sağlayan kaynaklar, aquaeductus'un güzergâhı ve mimarisi konusunda bir takım problemlere çözüm önerileri getirilmeye çalışılmıştır. Bu bakımdan Akdeniz havzasında, tamamına yakın bölümü Roma İmparatorluk Dönemi'ne tarihlendirilen aquaeductus'lar üzerine yapılan çalışmalar gözden geçirilip benzer sorunlar ve bunları gidermeye yönelik uygulanan mimari ve teknik önlemler ortaya konulmuştur. Ardından Phaselis'e su sağladığı belirtilen su kaynakları ve bunlardan elde edilen suyu taşımaya yönelik inşa edilen strüktürler yeniden incelenmiş; bu süreçte yeni tespit edilenler de koordinatları belirlenip kayıt altına alınmıştır.

Bu bağlamda gerçekleştirilen Phaselis Su Sistemleri ve Hidrografya Araştırmaları 4 bölüm içerisinde değerlendirilebilir:

1. Tahtalı Dağı doğu yamacı su kaynakları araştırması: Kentin ana su kaynağını oluşturduğu düşünülen ve Sıtma Pınarı ile Teleferik Alt İstasyonu arasında yer alan arazideki su kaynaklarının bulunması ve suyoluna ait kalıntıların incelenmesi,

2. Phaselis'in güneybatısında bulunan ve yöre halkı tarafından Phaselis suyoluna ait olduğu (aquaeductus) belirtilen kalıntıların yerinde incelenip su kaynaklarının araştırılması,

3. Kente su getiren suyolunun kemerler üzerinde bulunan bölümünün ölçüm ve hesaplarının yapılması, deniz içerisinde kalan kemer ayaklarının tespit edilerek fotoğraflanması,

4. Akropolis'te bulunan hidrolik strüktürlerin araştırılıp kayıt altına alınması.

\section{Tahtalı Dağı Doğu Yamacı Su Kaynakları Araştırması}

2015 yılı Phaselis Su Sistemleri ve Hidrografya Araştırmalarının ilk etabı kapsamında Tahtalı Dağı doğu yamacında, Teleferik Alt İstasyonu (yükseklik 726 m) ile Sıtma Pınarı mevkii (yükseklik 1029 m) arasında kalan su kaynakları incelenmiştir. Kentin su sistemleri üzerine önceki dönemlerde yapılan çalışmalarda Tamtır Tepesi ve Atamak Sırtı eteklerinde 3 farklı noktadaki pınarların kentin ana su kaynağını oluşturduğu görüşü hâkimdir². Buralardan elde edilen sular Roma Imparatorluk Dönemi'nde düzenlenen aquaeductus ile kent merkezine ulaştırılmıştır.

Bölgede yaptığımız incelemelerde daha önceki araştırmacılar tarafından yayınlarında belirtilenler dışında yeni su kaynakları, hidrolik strüktürler ve materyal kültür kalıntıları tespit

1 Söz konusu araştırma birikimine ilişkin bk. Schäfer 1981; Tüner Önen 2008; Tüner Önen - Akçay 2014; Arslan - Tüner Önen 2015.

2 Büyükyıldırım 1994, 80. 


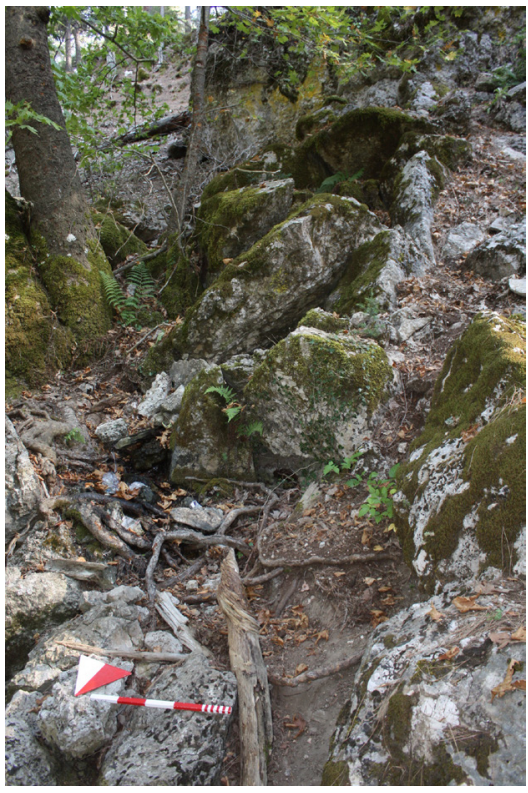

Fig. 1. Sitma Pınarı

edilmiştir. Uzun zamandır Çamyuva ve civarında yerleşik olup geçimini hayvancllıktan kazanan yörüklerin sürülerini otlatırken rastladıkları ve ekibe bildirdikleri su kaynakları ${ }^{3}$ bulunarak koordinatları çıkarılmış ve birlikte kayıt altına alınmıştır. Bunlardan su kaynaklarının ve suyolunun in-situ bölümlerinin koordinatları ve mimari özellikleri, bilinen en yüksek kottakinden başlayarak aşağıya doğru sıralanmıştır:

\section{Sitma Pınarı}

Sıtma Pınarı bölgede günümüze değin araştırmacılar tarafından tespit edilebilen kaynaklar arasında en yüksek seviyede yer alanıdır. Yüzeye çıktığı noktadan (enlem 36, 546552; boylam 30,466789; yükseklik 1029 m; hassasiyet H. 5 m, V. 12 m) doğu istikametine, daha aşağılarda bulunan Tamtır Pınarı'na doğru akmaktadır. Tepelerden kopan kaya blokları ve dökülen toprak örtüsüne rağmen suyun çıktığı bölgede, suyoluna ait büyük boyutlarda işlenmiş bloklar ve mimari düzenlemeler seçilebilmektedir (Fig. 1). Kaynaktan çıkan sular çıkış yönü doğrultusunda, güney-kuzey istikametinde, kesme taşlarla düzenlenen bir pınar derleme yapısı ile yönlendirilmiştir. Yılın en sıcak dönemlerinde bile Sıtma Pınarı'ndan su akmaktadır. Etrafta çok sayıda çınar ağacı ${ }^{4}$ bulunması dikkat çekicidir.

\section{Köy Pınarı}

Suların yüzeye ulaştığı mevkide akışı kontrol altına almaya yönelik (enlem 36,331620; boylam 30,283120; yükseklik 1013 m) pınar derleme yapısı kalıntılarına rastlanmıştır. Bunların dışında, arazinin büyük bir bölümü istinat duvarları ile kısmen düzleştirilerek teraslar oluşturulmuş, çitle örülü hayvan barınaklarının yanı sıra bir adet de kâgir yapı inşa edilmiştir. Coğrafi özellikleri ve içerisindeki kaynak nedeniyle senenin en sıcak periyodunu izleyen dönemde, Eylül ayı başlarında, daha yüksekteki yaylalardan aşağılara doğru inişe geçen yörükler bu alanda yaklaşık 2 ay konaklamaktadırlar ${ }^{5}$. Buradan çıkan sular arazinin eğimini izleyerek güneydoğuya, Oluksuz Pınar istikametine akmaktadırlar.

\section{Tamtır Kavaklıpınar}

Tamtır Pınarı (enlem 36,546640; boylam 30,469414; yükseklik 980 m; hassasiyet H. 5 m, V. 8 m) kente su sağlayan ana kaynaklardan biri olarak bilinmektedir. Burada çağlayan sular arazinin topografik özellikleri nedeniyle yaklaşık $70 \mathrm{~m}$ kuzeyde bulunan Oluksuz mevkiinden akanlarla birleşip Çatak'a inmiş olmalıdır. Suyun yeryüzüne çıktığı alanı koruma amacıyla kesme taşlarla dü-

3 Ahat Kızı, Kızalanı ve Kızıl Alan gibi farklı isimlerle bilinen bölgede iki adet su kaynağı olduğu yine uzun yıllardır yörede yaşayan yörükler tarafından dile getirilmiştir. Bu dönemde gitme fırsatı bulamadığımız fakat haritalar üzerinde yaptığımız çalışmalarda koordinatlarını yaklaşık olarak saptayabildiğimiz (enlem 36,334268; boylam 30,274807; yükseklik 1290 m) söz konusu alan Köy Pınarı'nın 1250 m kadar kuzeybatısında yer almaktadır. Yine harita üzerinde gerçekleştirdiğimiz incelemeler sonucunda buradaki suların Köy Pınarı ya da Çatak Su Gözü mevkiine ulaştırılmış olabileceği ihtimalinin göz ardı edilemeyeceği düşünülmektedir.

4 Sulak yerlerde, özellikle dere ve nehir yataklarında hızlı büyüdükleri bilinmektedir.

5 Araştırma esnasında Antalya ili, Kemer İlçesi, Tekirova Cumayeri Mahallesi'nde ikamet eden yörük ailelerden birinin burada konakladığına bizzat şahit olunmuştur. 


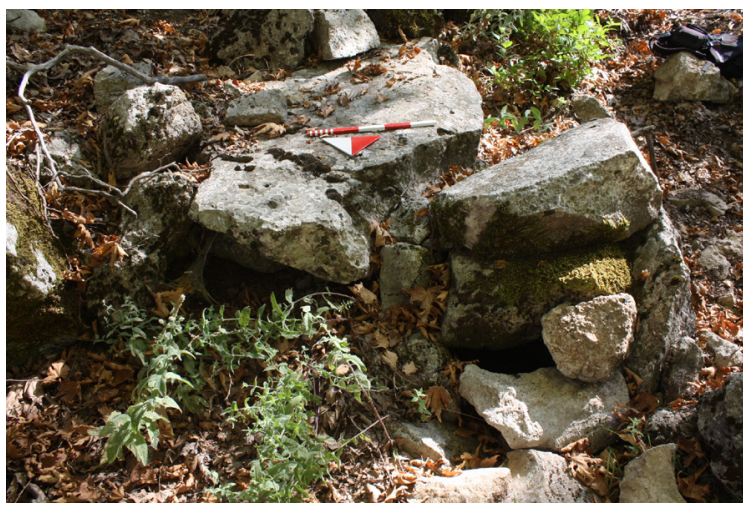

Fig. 2. Tamtır Kavaklı Pınar

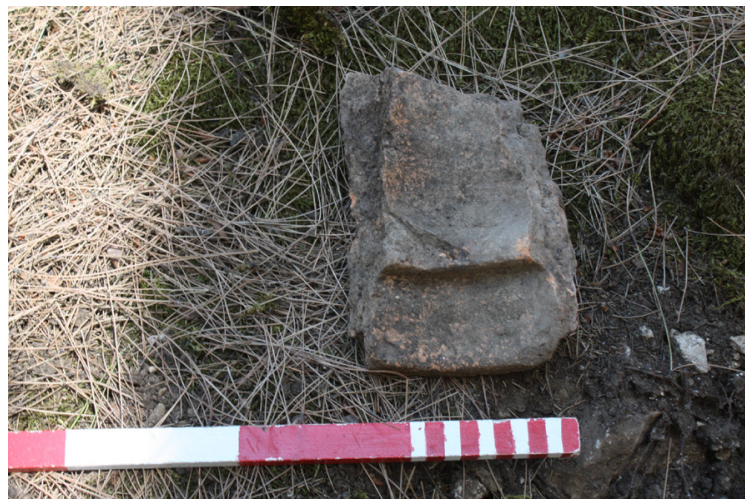

Fig. 3. Boru Parçası, Sandal Taş Mevkii

zenlenen pınar derleme yapısı zarar görmüş olmasına rağmen sektörde in-situ bloklar tespit edilmiştir (Fig. 2). Yine yakın çevrede çok sayıda kalın gövdeli, büyük çınar ağaçları bulunmaktadır.

\section{Oluksuz Pınar}

Tahtalı Dağı Kar Deresi mevkiine düşen karların erimesiyle oluşan bu kaynağın sularının daha aşağıdaki Çatak'ı beslediği ve ardından Tamtır'da Sıtma Pınarı, Kızalanı ve Köy Pınarı'ndan gelen sularla birleştikten sonra Phaselis'e indiği düşünülmektedir.

Araştırmaların yapıldığı dönemde suyun olmaması genişliği 4,5 metreye ulaşan dere yatağıyla tezat bir durum sergilemektedir.

Tamtır Kavaklıpınar ile Çatak Sugözü arasındaki araziden geçen Lykia Yolu'nun Sandal Taş mevkiinde (enlem 36,546928; boylam 30,471189; yükseklik 843 m; hassasiyet H. 5 m, V. $8 \mathrm{~m}$ ) gözlemlenen künk parçaları arasında sayıları az da olsa boruların uç kısımlarına denk gelen dişi ve erkek kısımlar bulunmaktadır (Fig. 3). Çeper kalınlığı 5,5 cm olan bu künklerin diğer parçayla bağlantısını sağlayan erkek uç uzunluğu da 5,5 cm'dir. Borunun iç kısmı ile erkek uç kalınlığı hafifçe incelerek 2,5 cm'ye inmektedir. Çeper içi ve erkek uç arası yükseklik ise $2 \mathrm{~cm}$ olarak ölçülmüştür.

\section{Çatak Sugözü}

Çatak Sugözü olarak adlandırılan ve yılın her döneminde suların çağladığı bu kaynak, yüksekliği yaklaşık $8 \mathrm{~m}$ olan kayalık ve çok dik bir yamacın dip kısmında bulunmaktadır (enlem 36,547214; boylam 30,472352; yükseklik 816 m; hassasiyet H. 1 m, V. 16 m). Kayaların üzerinde batıya doğru yönelen oyuğun ağız kısmını korumak amacıyla doğu-batı yönünde, kesme taşlarla örülü pınar derleme yapısı inşa edilmiştir. Kente taşınan suyun alındığı

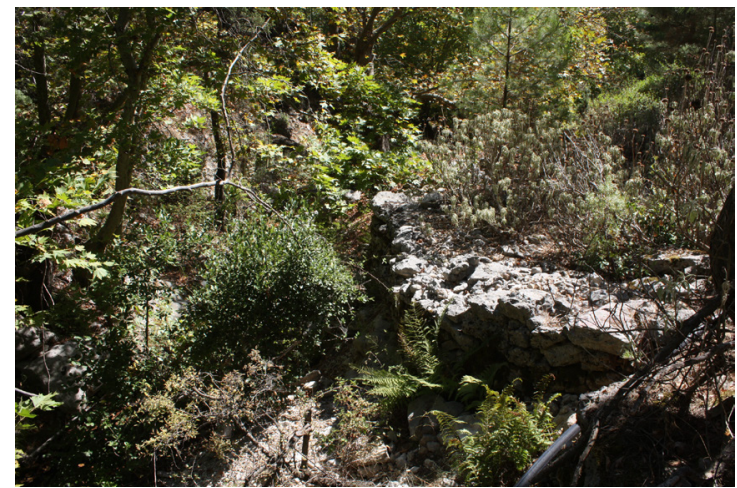

Fig. 4. Çatak Sugözü Su Alma Yapısı kaptajlardan birinin burada düzenlendiği görülür. Kaptajdan itibaren doğuya doğru örülen duvar 18,35 m mesafede kuzeydoğu istikametine yönlenip tekrar doğuya doğru devam etmektedir (Fig. 4). Kıvrım yerinde duvar kalınlığı 1,25 m ölçülmüştür. 


\section{Molla Deliği Mağarası}

Çatak Mevkii'ndeki toplam uzunluğu 549 m olan ${ }^{6}$ Molla Deliği Mağarası içerisinde gözlemlenen sarkıt oluşumları tavandan sular sızdığını, mağara ağzına yakın olup sifon işlevi gören çukurluk içerisinde bulunan kalın kum ve çakıl tabakası ise buradan bol miktarda suların aktığına işaret eder. Yöre sakinlerinden yağış mevsiminde dışarıya doğru suların basınçla fışkırdığını söyleyenler olsa da mağaranın boyutları böyle bir olasılığın zayıf olduğunu düşündürmektedir.

\section{Yardımtepe Mevkii/Demiroluk}

Sakarçağıl ve Çatak istikametinden Akboyun/Ayı İni mevkiine, doğuya doğru arazi boyunca devam eden aquaeductus'un Yardımtepe mevkiinin Demiroluk olarak anılan bölgesinde (enlem 36,541319; boylam 30,478198; yükseklik 771 m; hassasiyet H. 10 m, V. 12 m) suyu kesintisiz akmakta olan bir çeşme bulunmaktadır. Yakın geçmişte plastik borularla beslenmeye başlanmıştır.

\section{Akboyun/Ayı İni Mevkii}

Teleferik istasyonundan Tahtalı Dă̆ı'nın zirvelerine doğru uzanan patikanın ilk metrelerinde, $731 \mathrm{~m}$ yükseklikte, Akboyun/Ayı İni mevkiinde (enlem 36,540543; boylam 30,48 4320; hassasiyet H. 5 m, V. 6 m) aquaeductus'a ait çeşitli strüktürler bulunmaktadır. Suyolunun geçtiği güzergâhta ana kayaya oyulmuş kanallar ile üzerinden su kanalının (boruların) geçtiği, kimi yerde kesme taş, kimi yerde de moloz ve harç kullanılarak doğubatı istikametinde örülü duvar kalıntıları (Fig.

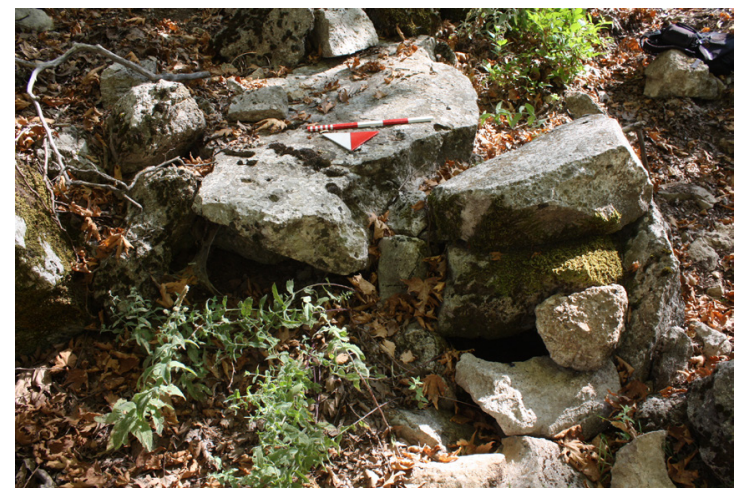

Fig. 5. Suyoluna Ait Duvar Kalıntısı Akboyun/Ayı Ini Mevkii 5) saptanmıştır. Patikanın kuzey kenarında dik bir yamacın başlangıcında uzanan duvar parçasının yaklaşık $15 \mathrm{~m}$ doğusunda, suyolu güzergâhının kuzey ve güneyinde yaklaşık 6 metre arayla iki adet rezervuar bulunmaktadır. İçerilerindeki toprak yığını ve yoğun vejetasyon detaylı araştırma yapılmasına engel olmaktadır.

\section{Tahtalı Dağı Doğu Yamacı Kaynakları Araştırması Sonuçlarının Değerlendirmesi}

2015 yılı araştırmaları kapsamında Tahtalı Dağı doğu yamacında Sıtma Pınarı ile teleferik istasyonu arasında yapılan incelemeler sonrasında suyolunu besleyen ana kaynakların Sıtma Pınarı ${ }^{7}$ ve Tamtır Kavaklı Pınar olduğu savı ağır basmaktadır. Sıtma Pınarı ile teleferik aşağı istasyonu arasında toplam 6 adet kaynak olduğu tespit edilmiştir. Batıda, daha yüksek seviyelerde bulunanlardan çıkan suların nasıl taşındığına dair bulgular sınırıdır. Çatak su gözü dışında diğer kaynaklarda sadece suların yüzeye çıktığı bölgelerde bir takım düzenlemeler bulunmaktadır. Buralarda yamaç döküntülerinin yoğunluğunun olası strüktürleri kaplamış olabileceği düşüncesi göz ardı edilmemeli, ileri dönemlerde kazı ya da sondaj çalışmaları yapılmalıdır. Bu kaynaklardan başka 1290 m yükseklikte 2 adet pınar olduğu bilinmektedir ${ }^{8}$. Suyoluna ait kalıntılar, araştırmaların kazı sonrası ortaya çıkarılanlara değil de çıplak gözle yüzeyde bulunanlara dayanmakta olup

\footnotetext{
Güldalı et al. 1991, 19.

Silma Pınarı olarak da bilinmektedir. Krş. dn. 2.
} 
kısıtlı kalmaktadır. Değerlendirme yapabilmek için kaynaklar arası mesafeler kuş uçuşu olarak ele alınıp bulunan değerler ve eğim dereceleri aşağıda sunulmaktadır:

- Sıtma Pınarı'ndan (yükseklik 1029 m) Çatak Sugözü'ne (yükseklik 816 m) mesafe yaklaşık $538 \mathrm{~m}$, iki yer arasındaki eğim farkı 213 m'dir. Bu rakamlara göre ortalama eğim 395 m/km'dir (39,5\%).

- Çatak Sugözü'nden $(816 \mathrm{~m})$ Yardım Tepe'ye $(771 \mathrm{~m})$ uzaklık yaklaşık $840 \mathrm{~m}$, iki bölge arasındaki eğim $45 \mathrm{~m}$, ortalama eğim 57,14 m/km'dir (5,714\%).

- Yardım Tepe'den (771 m) Akboyun/Ayı İni mevkiine (731 m) mesafe 560 m, her iki yer arasındaki eğim farkı $40 \mathrm{~m}$, ortalama eğim ise 71,42 m/km'dir (7,142\%).

- Akboyun/Ayı İni Mevkii'nden kent içindeki su kemeri kalıntılarına kadar ölçülen mesafe yaklaşık 6300 m'dir. Söz konusu değerlerden yola çıkarak her iki alan arasındaki eğim farkı $720 \mathrm{~m}$ kabul edildiğinde ${ }^{9}$ ortalama eğim yaklaşık $114,25 \mathrm{~m} / \mathrm{km}$ $(11,425 \%)$ bulunur.

- Son olarak Sıtma Pınarı'ndan (1029 m) kent içindeki suyolu kalıntılarına bir ölçüm yapıldığında aradaki mesafe yaklaşık $8020 \mathrm{~m}$, iki nokta arasındaki eğim farkı yaklaşık $1020 \mathrm{~m}$, ortalama eğim ise $127,18 \mathrm{~m} / \mathrm{km}$ hesaplanır (12,72 \%).

Burada bulduğumuz rakamları, günümüze değin bilinen diğer Roma suyollarıyla karşılaştırmadan bir değerlendirmeye gidildiğinde çıkacak sonuçlar güvenilir olmayacaktır. Bu nedenle suyollarını, sebep-sonuç ilişkisi bağlamında, mimari ve tarihi gelişimlerini de göz önünde bulundurarak ele almak gerekmektedir.

Anadolu'daki birçok kentin kurulduğu dönemlerdeki su ihtiyacı ile Roma İmparatorluk Dönemi'ndeki su ihtiyacı arasında büyük farklar olduğu şüphesizdir. Bunun sebebi sadece demografik gelişmeler sonucu değişen tarımsal, endüstriyel ve bireysel temizliğe yönelik su kullanımındaki artış değil, aynı zamanda Roma Imparatorluk Dönemi şehirciliğinin vazgeçilmez kamu yapıları arasında yer alan ve yüksek miktarlarda su gerektiren hamamlar ve anıtsal çeşmelerin kent merkezlerinde inşasıdır. Buna bağlı olarak yine aynı dönemde Roma ve eyaletlerdeki diğer kentler, etkileyici boyutlara sahip, mühendislik harikası suyolları ile donatılmışlardır.

Kent içerisinde kalan bölümünün büyük bir kısmı kemerler üzerinde inşa edilen suyolu Phaselis'in su ihtiyacını karşılamaya yönelik düzenlemelerden sadece biridir.

Aquaeductus ${ }^{10}$ (suyolu) sözcüğünün kökeni incelendiğinde, su anlamına gelen aqua/ae ve getirmek, götürmek, yönlendirmek anlamlarındaki ducere fiilinden gelen ductus kelimelerinden türetildiği ortaya çıkar. Suyun kaynağından itibaren kullanılacağı yere kadar izlediği güzergâhın tamamına verilen addır. Açık ve örtülü kanallar, pişmiş toprak ve kurşun borular, tüneller, galeriler, kemer ve duvar üzerine yerleştirilmiş borular, sifon, basınç kuleleri, düşü yapıları ve çökelti havuzları gibi bölümlerden oluşur. Günümüzde ise Türkçe literatürde bu deyimin (aquaeductus) yaygın olarak, yanılgılı bir şekilde, sadece suyolunun kemerler üzerinde kalan ve genelde ayakta kalan, iyi korunagelmiş bölümlerini belirtmek amacıyla kullanıldığı görülür. Suyolu ${ }^{11}$, üzeri açık ya da örtülü, kimi zaman yeraltında, tünel ya da galeri şeklinde, kimi zaman yüzeyde, gerektiğinde duvarlar ve kemerler (opus arcuatum) üzerinde taşınan bir kanal (specus) olabileceği gibi bir ya

9 Su kemerlerinin yüksekliği yıkılma riski nedeniyle alınamadığından ortalama 10 m olarak kabul edilmiştir.

10 Litaudon 2004, 71.

11 Bonnin 1984, 179. 
da daha fazla toprak ve kurşun borudan da oluşabilir ${ }^{12}$. Sular genellikle yüksekliği genişliğine oranla daha fazla, kesiti dörtgen planlı bir kanal içerisinde, hafif bir eğimle (1 km mesafede $1 \mathrm{~m}$ ) ve düşük bir hızla (saniyede 1 metreden daha az) akar ${ }^{13}$. Yerçekiminin oluşturduğu ağırlık kuvveti, açık yüzeyli sistemlerde serbest yüzeyli akımı (cazibe ile iletim) sağlar ve böylelikle sular, içerisinde bulunduğu kanalın eğimini izleyerek istenilen bölgeye ulaştırılır. Sadece suyu bir kaynaktan kullanılacağı alana götürürken değil, aynı zamanda drenaj gerektiren bölgelerde de, mümkün olan en fazla miktardaki suyu yine mümkün olan en düşük eğimle taşımak gerekir ${ }^{14}$.

Antikitenin en önemli mühendislik eserleri arasında ilk sıralarda yer alan aquaeductus'ların eğimi birçok araştırma ve tartışmaya konu olmuştur. Eğim, suyun akış hızını belirlediğinden kontrol altına alınmalı ve böylelikle yapının mimari açıdan zarar görmesinin önüne geçilmelidir. Suyolunu planlayan tasarımcılar çok ince hesaplarla suyun üzerinde ilerleyeceği yüzeyin özelliklerini de göz önünde bulundurarak optimum akışı sağlamayı amaçlamışlardır. Bunu yaparken suyun akış hızını (saniyede 1,5 m'nin altında olmalıydı) düşürmek için yüksekliklerle oynamış ve aquaeductus'a kısa sürede büyük zararlar verilmesinin önüne geçmişlerdir ${ }^{15}$.

Akboyun mevkiinde kayalara oyulmuş kanallar ve in-situ tespit edilen duvar kalıntılarının da suyolunun eğimini düzenleyerek suyun akışını kontrol altına almaya ve böylelikle basıncı düşürüp kanal ve boruların zarar görmesini engellemeye yönelik olduğu şüphesizdir ${ }^{16}$.

Kimi zaman uzak mesafelerde bulunan ya da suyu yetersiz gelen kaynaklar düz bir hat oluştursalar bile gerekli eğim sağlanamayabilir. Bu ve benzeri durumlarda, söz konusu kaynaklar projelere dâhil edilmeyip kullanım dışı bırakılmışlardır. Tersi söz konusu olup da aşırı eğimle karşılaşıldığında ya da kaynaktan kente suyu getirmek için engebeli arazi, vadi, nehir ya da çukur gibi doğal engellerin aşılması gerektiğinde ise farklı çözümler bulunmuştur. Örneğin suyolu güzergâhı yükselti eğrilerine uygun olarak kıvrımlı ve daha uzun inşa edilerek uygun eğim elde edilmiştir ${ }^{17}$.

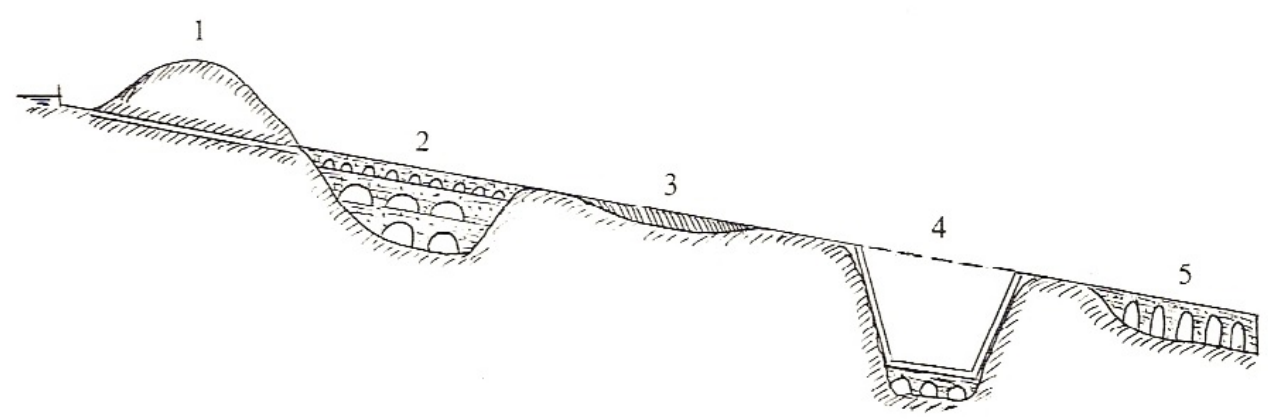

Fig. 6. Suyolu Bölümler (Bonnin 1984, 180 fig. 10. 3)

12 Pişmiş toprak ve kurşun boruların dışında ağaç ve deriden elde edilen boruların da suyollarında kullanıldığı bilinmektedir.

13 Burdy 2002, 25.

14 Rouse - Ince 1957, 118.

15 Fabre et al. 2005, 9.

16 Suyun taşımasında kullanılan teknikler aşağıda detaylı bir şekilde ele alınmaktadır.

17 Hodges 2000, 52-53. 
MÖ II. yüzyılın sonlarından itibaren ortaya çıkan üç yenilik; tünel, ters sifon ve duvar ya da kemerler üzerine yerleştirilen kanallar konunun uzmanlarına önlerine çıkan bu engelleri aşmak için kolaylıklar sağlamıştır (Fig. 6) ${ }^{18}$.

Fig. 6'da da görüleceği üzere, sanat yapılarından kemerler üç farklı işleve sahip olabilirler. Bunlar, küçük vadilerin geçilmesinde direkt kanalın taşınması, bir geçidin, vadinin tabanında, üzerine sifonun yerleştirilmesi ve son olarak da suyolunun kente belirli bir yükseklikte varmasıdır. Bu önlem sayesinde su dağıtımı için gereken basınç elde edilir ve en yüksek yerleşim bölgelerine kadar suyun ulaşması sağlanır.

Suyun akışına en elverişli eğimi sağlamak amacıyla suyolunun kat etmesi gereken mesafenin uzadığı, kimi yerde bir kaç kat arttığına Lugdunum (Lyon) kentine su sağlayan dört aquaeductus iyi bir örnek oluşturur ${ }^{19}$.

\begin{tabular}{|ccccc|}
\hline Suyolu & Uzunluk $(\mathrm{km})$ & Kuş uçuşu $(\mathrm{km})$ & Kaynak yüksekliği & Varış yüksekliği \\
Crapon & 25 & 19 & 700 & 280 \\
Mont d'Or & 28 & 20 & 350 & 260 \\
Brévenne & 66 & 26 & 630 & 280 \\
Gier & $86^{20}$ & 42 & 405 & 300 \\
\hline
\end{tabular}

Tablo 1. Lugdunum Suyolları

Romalılar ampirik yöntemlerle suyun akışı için gerekli en düşük eğimi belirlemelerini sağlayan kavramlara sahiptiler ${ }^{21}$. Vitruvius eserinin suya ayrılan bölümünde ${ }^{22}$ suyun kente ve evlere ulaştırılması için gerekli aletleri belirtip (dioptra, chorobate) tanımlarını verdikten sonra kanalın eğiminin kilometrede 5 metreden $(0,5 \%)$ daha az olmamasını tavsiye etmektedir. Söz konusu miktarı çok abartıı bulan araştırmacılar yaptıkları çalışmalar sonrasında belgenin değişikliğe uğramış olabileceğini ve semipes ölçü biriminin sicilius (1/48 ayak) şeklinde değiştirilmesi gerektiğini belirtirler ${ }^{23}$. Ardından yaklaşık bir asır sonra Yaşılı Plinius (XXXI. VI. 1) suyu kaynağından itibaren taşımanın en iyi yöntemi olarak "100 ayak mesafe için en az 1/4 uncia" ${ }^{24}(0,02 \%)$ eğime sahip, iki parmak kalınlığında ve ilkinin ucu bir sonrakinin içerisine geçen toprak boruları tavsiye eder.

Roma suyolları konusunda hem antikçağ yazarlarının eserlerini (Plinius; Frontinius) hem de 19. yüzyıl sonlarında başlayan ${ }^{25}$ (C. Germain de Montauzan - A. Léger) ve son yıllarda sayıları

18 Bonnin 1984, 180 fig. 10.3.

19 Bonnin 1984, 204 tab. 10.6 kullanılmış, son bulgulara göre değerlerde düzeltmeler yapılmıştır.

20 Lyon suyolları üzerine çalışmalar yapan Burdy üç farklı sektöre ayırarak ele aldığı Gier suyolunun ilk bölümü için Bonnin'in verdiğinden farklı rakam vermektedir. Kuş uçuşu $17 \mathrm{~km}$ olan mesafeyi kat etmek üzere inşa edilen suyolunun uzunluğu, sekiz adet tünel ve otuzdan fazla su köprüsü vasıtasıyla toplam 47 km'ye ulaşmaktadır. Bu nedenle tablonun ilgili bölümünde düzeltme yapma gereği doğmuştur. Bk. Burdy 2002, 39.

21 Bonnin 1984, 193.

22 Vitr. de Arch. VIII.

23 Bourgeois 1992, 281.

24 Libramentum aquae in centenos pedes sicilici minimum erit. Bk. Söz konusu eğim günümüz ölçüm değerlerine göre 0,2083 metreye denk gelmektedir. Farklı çeviriler içerisinde söz konusu ölçünün değişik birimler kullanılarak verildiği gözlemlenmiştir. Bk. Plin. nat. XXXI.

25 Léger 1875; de Montauzan 1897. 
gün geçtikçe artan detaylı çalışmaların bir bölümünü (A. Grenier, P. Leveau, G. Garbrecht, V. Lassale, J. Burdy $)^{26}$ inceleyen J. Bonnin suyollarının eğimleri konusunda tespit edilen değerlerin büyük farklılıklar ortaya koyduğunu, suyun akışı için 1 kilometre mesafede 0,28 m (0,028 \%) eğimin yeterli olacağını vurgular ${ }^{27}$.

Hodge ise Roma suyolları içerisinde, en detaylı araştırmalara konu olanlardan Gier (Lyon) suyoluyla önemli gördüğü diğer bazı suyollarını ele alıp değerlendirmiş ve sonra bir genellemeye giderek aquaeductus'un eğiminin kilometrede 1,5 m ile $3 \mathrm{~m}$ arasında değiştiğini (0,15-0,3 \%) ifade etmiştir ${ }^{28}$. Hodge'un çalışmasının son bölümünde; aquaeductus'larda tespit edilen en fazla eğimin, 1 km için 28 m'lik (2,8 \%) değerle Kartaca suyolunun Zaghouan - Moghrane arasındaki 6 km'lik bölümde bulunduğu görülmektedir. Aynı çalışma içerisinde suyolunun tamamında ortalama eğimin en fazla olduğu aquaeductus'un 16,4 m/km ile Segovia suyolu olduğu yer almaktadır. Bilinen en düşük eğim ise, ortalaması 0,34 m/ $/ \mathrm{mm}$ hesaplanan 49,75 km uzunluğundaki Nimes suyolunun $0,07 \mathrm{~m} / \mathrm{km}$ değerlere sahip bölümünde görülür. Bonnin'in Nimes aquaeductus'u için verdiği değerler ile Hodge'un çalışmalarındakiler farklııı göstermektedir ${ }^{29}$. Bonnin'in hesaplarında kaynak kotu 76,06 m, varış yeri ise 59,04 m olup aradaki değişim 17 m'dir. Yine aquaeductus'un ilk 16 km'sinin ortalama eğimi 0,67 m/km, kalan $34 \mathrm{~km}$ için ise 0,187 $\mathrm{m} / \mathrm{km}$ 'dir. Topografik şartlar suyolunun günümüzde Roma Dünyası'nın en yüksek yapısı olarak $(48,77 \mathrm{~m})$ bilinen Le Pont du Gard'a ulaşmadan daha düşük kota inmesini empoze etmiş böylelikle köprü günümüzdeki yüksekliğiyle sınırlandırılabilmiştir.

Mailhac suyolunun ortalama eğimi $2 \mathrm{~m} / \mathrm{km}^{30}$, Arles kentine su sağlayan $48 \mathrm{~km}$ uzunluğundaki, başlangıç ve varış noktaları arasındaki kot farkı $38 \mathrm{~m}$ olan aquaeductus'unkisi ise 0,79 $\mathrm{m} / \mathrm{km}^{\prime} \mathrm{dir}^{31}$. Söz konusu değerlerin farklı bölgelerde de tavsiye edilen genel ortalamalara yakın oldukları bilinmektedir. İspanya'da kaynağından kente uzunluğu 8,8 km'yi bulan Tiermes suyolunun ortalama eğimi 0,49\%'dur ${ }^{32}$.

Pisidia Antiokheia'sına su sağlayan aquaeducutus'a ait kalıntıların su kaynağına en yakın olanları kaptaja 4 km mesafede tespit edilmiştir. Araştırmacılar ${ }^{33}$, ilk $2 \mathrm{~km}$ boyunca eğimi bir an önce daha elverişli seviyeye getirmek amacıyla bir takım düzenlemeler yapılmış olabileceği olasılı̆̆ını da dikkate alarak kanalın kalıntıların bulunduğu alana kadar araziyi izlediğini varsaydıklarını belirtirler. Yamacın sert bir şekilde dikleştiği yerde, kanalın zemininin yatay ve uç uca yerleştirilen çok sayıda, önemli ölçülerdeki (0,62 m x 0,45 m) dörtgen tegulae'lerden oluştuğu ve iki adet dirsek yaparak yön değiştirdiği tespit edilmiştir. 1465 m kotta bulunduğu var sayılan kaynaktan ${ }^{34}$ kent içerisindeki nympheium'un yakınında, 1178 m kotundaki rezervuara değin toplam uzunluğu 11 km'yi bulan aquaeductus'un uçları arasındaki yükseklik farkı 287 m'dir. Buradaki rakamlardan yola çıkıldığında elde edilecek ortalama eğim değeri ise $26,1 \mathrm{~m} / \mathrm{km}$ 'dir (2,61\%). Arazide tespit

26 Grenier 1960; Leveau 1976; 1979, 8-19; Garbrecht 1979, 26-33; Lassale 1979, 62-73; Burdy - Audin 1979, 52-61.

27 Bonnin 1984, 193 vd.

28 Hodge 2002, 216.

29 Bonnin1984, 208.

30 Harfouche et al. 2005, 125.

31 Liot 1963, 296.

32 Del Cura 2001, 28.

33 Burdy - Taşlıalan 1997, 160.

34 Burdy - Taşlıalan 1997, 161-162. 
edilen buluntulara dayanaraktan hesap edildiğinde ise, suyolunun doğuda bulunan kalıntılarıyla sifon arasında tahkim edilen kesitinin uzunluğu $6 \mathrm{~km}$ olup ortalama eğim $6 \mathrm{~m} / \mathrm{km}$ 'dir. Araştırmacılar sadece bu verilerle yapılan hesaplamanın eğimi bulmada yetersiz kaldığını, topografik konteksti ve kalıntıların tegulae içeren bölümünü de dikkate alarak gerçek değere yakın rakamlara ulaşılacağı görüşünde olduklarını ifade ederler. Kısmen yıkık bir durumda tespit edilen tegulae içeren bölümün uzunluğu yaklaşık $200 \mathrm{~m}$ olup $75 \mathrm{~m} / \mathrm{km}$ 'lik bir eğime sahiptir. Böylelikle 15 m'lik bir seviye değişikliği (düşü/şüt) sağlanmıştır. Bu hesaplamalar sonucunda Burdy ve Taşlıalan Pisidia Antiokheia'sı suyolunun ortalama eğiminin $2 \mathrm{~m} / \mathrm{km}$ olduğunu savlamaktadırlar ${ }^{35}$.

Phaselis suyolu için bulduğumuz eğim değerleri yukarıda saydığımız, Akdeniz havzasında inşa edilmiş, günümüzde bilinen Roma suyollarına göre çok büyük farklılıklar ortaya koymaktadır. Aynı dönemlere tarihlenen aquaeductus'lar içerisinde benzer eğime sahip herhangi bir suyoluna rastlanmamıştır.

Yaptığımız çalışmalar sonucunda bazı suyollarının sadece sınırlı bölümlerinde yüksek eğimler olduğu görülmüştür. Kessener'in araştırmaları ${ }^{36}$, Aspendos suyolunu besleyen Pınarbaşı kaynağından itibaren güneye doğru yaklaşık 500 m'lik bir kesitte eğimin yaklaşık 160-170 m/km civarında olduğunu, erozyon nedeniyle arazi yüzeyindeki değişikliklerin kanalı yıktığını ve akan toprağın kalıntıları örttüğünü ortaya çıkarmıştır.

Fransa'nın güneydoğusunda, Frejus kentine su sağlayan 39.400 m uzunluğundaki Mons ${ }^{37}$ aquaeductus'unun Callian mevkiindeki sınırlı bir bölümünün eğimi 100 m/km'ye ulaşmakta olup düzenleyici işlevi gören en az bir dolusavağa sahiptir ${ }^{38}$. Yine aynı çalışma içerisinde Brévenne suyolunun çok sayıda düşüye sahip olduğu, Courzieu'de eğimin, 200 m'lik bir bölümde 44 m'ye (220 m/km'ye denk gelmektedir, $22 \%$ ), Chevinay'de ise 250 m'lik bir mesafede 87 m'ye ulaştığı (348/km, 34,8 \%) belirtilmektedir.

Chanson, daha önce konu üzerinde çalışmış iki uzmanın (Garbrecht ve Hodge) Romalı mühendislerin momentumun korunumu prensiplerini anlamadıklarını öne sürdüğünü, oysaki ìskenderiyeli Heron (MÖ 10 - MS 70) zamanında ve sonrasında Kuzey Afrika ve Galya'da çok sayıda aquaeductus inşa edildiği gerçeğini dile getirir. Heron'un şöhreti bu prensipleri bilmesinden kaynaklanmaktadır ve çalışmaları dönemin mühendisleri üzerinde etkili olmuştur ${ }^{39}$.

Birçok suyolu ani seviye değişiklikleriyle kesintiye uğrayabilen bölümlere ve düz devam eden parçalara sahiptirler. Chanson aquaeductus'un düzenli-üniform akım sağladıkları yönündeki genel düşüncenin tersine, ani seviye değişikliklerinin kritik üstü akışlara (supercritical flows) neden olduğunu, su iletiminin sorunsuz olarak sağlanabilmesi için bir dizi teknik önlemler alınması gerektiğine dikkat çeker ${ }^{40}$.

Arazideki eğimin değişkenlikler göstermesi tasarımcıların güzergâh boyunca farklı teknikler kullanarak çözüm aramasına neden olmuştur. Romalılar bu sorunu çözümlemek amacıyla başlıca üç farklı metot kullanmışlardır: Düşü ve sakinleştirme havuzları (maslak), kanal içerisinde basa-

\footnotetext{
35 Burdy - Taşlıalan 1997, 164.

36 Kessener 2000, 109. Kendisiyle son olarak 03.04.2016 tarihinde yaptığımız yazışmada bu eğimin $120 \mathrm{~m} / \mathrm{km}$ olduğunu belirtmiştir. Değerli görüşlerini paylaştığı için kendisine teşekkür ederim.

37 Toplam eğimi 39,4 km için sadece 481 m'dir. Bk. Chanson 2002, 44 tab. 1.

38 Chanson 2002, 44.

39 Chanson 2002, 43.

40 Chanson 2000, 47 vd.
} 
maklı enerji kırıcılar ve enerji kırma kuyuları ${ }^{41}$.

Yukarıda verilen metotlardan sonuncusu, kanalın zeminine açılan düşey, dik bir kuyu olup kanal içerisindeki suların ani bir düşüşle hızının kesilmesini sağlar. Romalı mühendisler, gerek duyulduğu durumlarda çok sayıda enerji kırma kuyusunu birbiri ardına, kaskat şeklinde sıralayarak aşırı eğim sorununa çare bulmuşlar böylelikle çok kuvvetli yüklemelerin de önüne geçebilmişlerdir.

Aşağıda farklı bölgelerden örneklerini sıraladığımız bu tür yapılar ve özellikleri Chanson'un bir diğer çalışmasında detaylıca ele alınmaktadı ${ }^{42}$ :

-Yzeron aquaeductus'u (Lyon, Fransa), Vaugneray bölümü: 8 adet dikdörtgen planlı enerji kırma kuyusu, kanal genişliği 0,4 m; yükseklik 2,5 m

-Yzeron aquaeductus'u (Lyon, Fransa), Recret/Grézieu-la-Varenne bölümü: 15 adet dikdörtgen planlı enerji kırma kuyusu, kanal genişliği 0,55 m; yükseklik 2,5 m

-Chabet Illelouine, Cherchell aquaeductus'u (Cezayir): dairesel formlu, 2,4 m çapında, 0,8 m yükseklikte; enerji kırma kuyularının izlediği, kanal genişliği 0,94 m olan 4 seri dik düşü

-Moulin Romain, Gunugu aquaeductus'u, (Tunus): 4-5 adet dairesel formlu, 0,8 m çapında, 3,5 m yükseklikte enerji kırma kuyusu, kanal genişliği 0,86 m

-Beaulieu aquaeductus'u, Aix-en-Provence (Fransa): dik düşü ve enerji kırma kuyusu kombinasyonu

-Grand thermes, Cuicul aquaeductus'u, (Tunus): kent içi dağıtım hattında kanal genişliği 0,45 m, 0,8 m çapında, yüksekliği 0,4 m'den 1 m'ye değişen, 4 adet dairesel formlu enerji kırma kuyusu serisi

-Mechernich-Lessenich, Köln aquaeductus'u (Almanya): bir adet dikdörtgen planlı dik bölüme yerleştirilmiş enerji kırma kuyusu

-Cerro de los Pinos, Valdepuentes aquaeductus'u (Kordoba, İspanya): Valdepuntes su köprüsü üst kesimi. Genişlikleri 0,55 m den 0,6 m arası değişen $3 \mathrm{~m}$ yükseklikte 34 adet dairesel formlu enerji kırma kuyusu serisi. 3 adet alışılışın dışında, 90 dereceli dik baca, spiramina

-Madinat-al-Zhara, Valdepuentes aquaeductus'u (Kordoba, İspanya): 7 adet dairesel enerji kırma kuyusu

Morvan tepelerinin yakınında konuşlanan Autun kentine su sağlayan aquaeductus ise yüksekliği 4,40 m'yi geçen, sayıları yirminin üzerinde kaskata sahiptir ${ }^{43}$.

Aquaeductus güzergâhlarında enerji kırma kuyularından başka korunaklı düşüler, vanalı kaskatlar ve mütevazı ölçülerde havuzlar da yer alır. Vadi geçişinde su kanallarını taşıyacak ke-

41 Enerji kırma kuyusu terimi, yabancı dillerde söz konusu strüktür için kullanılan tabirlerin (İngilizce: dropshaft; Fransızca: puits de rupture) Türkçe'de ifade ettikleri anlamlar düşünülerek seçilmiştir. Literatürde kullanılan denge bacası ve şaft deyimleri farkı strüktürler için de kullanıldığından yukarıdaki deyim daha uygun görülmüştür.

42 Chanson 2001, 59.

43 Duval 1989, 1101 vd. 


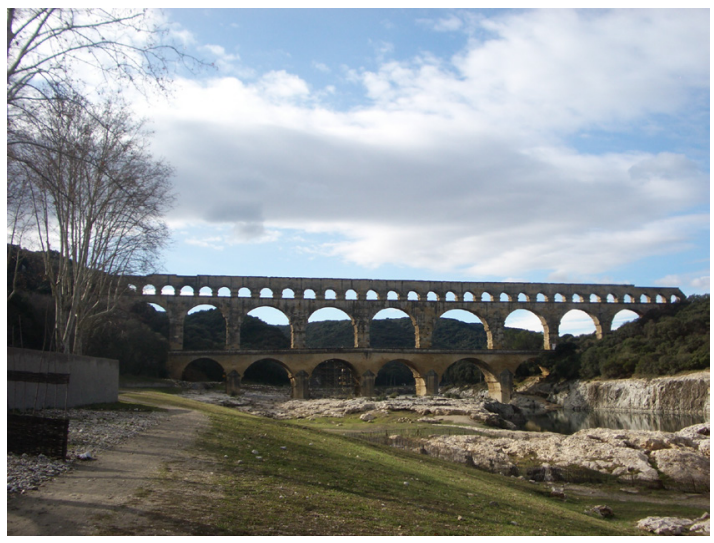

Fig. 7. Le Pont du Gard

merli yapının eğiminin fazla olması gereken durumlarda, öncesinde, daha yüksek kesimde dik bir kanal, basınç kırma kuyusu ya da düşü tahkim edilerek sorun giderilirdi. Nimes suyolunun (Fig. 7) Gardon geçişinde bu tür bir çözüm uygulanmıştır.

Aquaeductus içerisinde akan suyun hızı sedimanları uzak mesafelere taşımak için yeterli değildi. Bu sebeple suyolunun tıkanıp kullanım dışı kalmasına neden olabilecek kalker riskini önlemek için kimi zaman su kanallarının zeminlerine çukurlar açılmıştır.

Suyolları üzerindeki rezervuarlardan bilhassa eğimin fazla olduğu kesimlerde düzenlenenlerinin çökeltme havuzu olduğuna dair kesin veriler bulunmamakta, daha çok enerji kırmak için, sakinleştirme havuzu olarak yerleştirildikleri düşünülmektedir ${ }^{44}$. Örneğin Korinthos Alepotrypa'daki düşünün hemen aşağısındaki rezervuarın amacı suyun enerjisini kırmaktır. Chanson incelediği dört farklı suyolunda bulunan havuzların ölçülerini akan suyun miktarıyla karşılaştırdığında bu yapıların verimliliğinin 50\%'nin altında kaldığını, su içerisindeki tortu miktarının en düşük değerlerden hesaplanması durumunda bile bu havuzların her gün dolacağını ve suların kesilerek temizlik yapılması gerektiğini ortaya koymuştur.

Yukarıda sıraladığımız suyollarının coğrafi konumları göz önüne alındığında, Chanson'un Roma suyolları üzerine yaptığı çalışmalarında karşımıza çıkan mimari ve teknik önlemlerin kaynak ve kent arasındaki eğimin çok fazla olduğu Phaselis suyolu güzergâhında da kullanılmış olabileceği düşünülebilir.

\section{Güneybatı Suyolu Araştırmaları}

Phaselis'in güneybatısında, Cumayeri Mahallesi'nde bulunan ve yöre halkınca suyolu (aquaeductus) olarak bilinen kalıntılar incelenmiştir. M. Karakoyunlu'ya ait ağılların batısında, yamaçtan inen güneybatı-kuzeydoğu istikametinde devam eden moloz ve harç kullanılarak inşa edilmiş uzun bir duvar kalıntısı (enlem 36,516226; boylam 30,516621; yükseklik $23 \mathrm{~m}$; hassasiyet H. $5 \mathrm{~m}, \mathrm{~V} .6 \mathrm{~m}$ ) bulunmaktadır (Fig. 8). Söz konusu duvar, alanda yapılan trafo inşaatı ve yüksek gerilim hattı direkleri yerleştirme çalışmaları sebebiyle kesintiye uğramaktadır. Araştırma sürecinde aynı istikamette düzenli aralıklarla devam eden kemer ayakları olması muhtemel diğer kalıntılar da tespit edilmiştir.

Bu duvarın otel inşaatı için tahsis edilen alanda ${ }^{45}$ Antalya Arkeoloji Müzesi Müdürlüğü'nce yapılan kazılar neti-

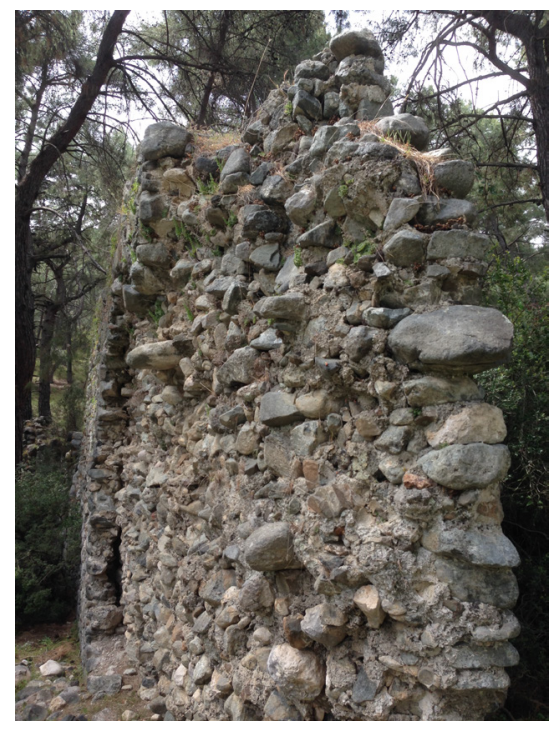

Fig. 8. Cumayeri Mevkii Suyolu

44 Chanson 2000, 49-50.

452015 yılında kamu oyununun tepkisi ve STK'nın mücadeleleri sonrasında mahkeme tarafından inşaat izni iptal edilmiştir. 
cesinde gün ışığına çıkarılan duvar ile benzer özelliklere sahip olduğu görülmektedir. Konumları gereği iki duvar arasında bir ilişki söz konusu olabilir. Bu olasılığın doğrulanması ise ancak gelecek dönemlerde yapılacak, ölçüm, sondaj ya da jeoradar çalışmalarıyla mümkün olacaktır.

\section{Suyolunun Kent İçerisindeki Kemerli Bölümü Araştırmaları}

Yukarıda belirttiğimiz üzere kente dağııımı yapılacak olan suların yine kente belirli bir yükseklikte varması gerekmektedir. Phaselis'e su sağlayan kanallar kentin kuzeybatısındaki tepenin doğu yamacını takip ederek agoraya doğru uzanmaktadır. Aquaeductus'un kent içerisinde yer alan bölümü duvar ve kemerler üzerinde iki farklı biçimde inşa edilmiştir. 2015 yılı hidrolik sistemler araştırmaları projesi içerisinde suyolunun kemerler üzerinde yer alan bölümünde inceleme ve ölçüm çalışmaları gerçekleştirilmiş ve kayıt altına alınmıştır.

Araştırmanın başlangııında suyolunun kemerler üzerindeki bölümünün eğimini hesaplamak amacıyla öncelikle terracotta boruların üzerine yerleştirildiği kemerleri taşıyan dikmeler ve impostum yükseklikleri arasındaki değişimlerin saptanması planlanmıştır.

Kemerlerin üzerinde yer alan harçlı duvarın önceki dönemlerde gerçekleşen kazı ve temizlik çalışmaları sürecinde onarıma uğradıkları, kent hakkında daha önce yapılan çalışmalardan üst üste yerleştirildikleri bilinen iki adet borunun ise artık yerlerinde olmadıkları ve duvar yüksekliğinin düzensiz olarak restore edildiği tespit edilmiştir. Bu gözlemler, günümüz şartlarında öngörülen eğim hesaplamasının güvenilebilir bir sonuç vermeyeceğini açıkça ortaya koymaktadır. Söz konusu eğimin, kente su getiren aquaeductus'un kemerler ve duvar üzerinde yer alan bölümlerinin kuzey ucu ile güneyde, kent içerisindeki varış noktasındaki seviyesinin gelecek dönemlerde yapılacak kazılar sonrasında ortaya çıkarılmasını izleyen süreçte hesaplanması daha uygun olacaktır. Bu nedenle araştırmalara aquaeductus'un mimari yapısı incelenerek devam edilmiş, güneyde bulunan ilk kemer açıklığı ve dikmeden itibaren kuzeye doğru ölçümler gerçekleştirilmiştir.

\section{Suyolunun Günümüzdeki Durumu}

Suyolunun güney kısmını oluşturan duvar, dikmeler ve kemerler strüktürün geri kalan bölümüne kıyasla daha iyi durumda olduklarından numaralandırmaya suyun geliş yönünden (kuzey) değil de aksi istikametten başlanmıştır. Güney uçta bulunan duvardan itibaren ilk 4 adet kemer ile 8., 9. ve 10. kemerler iyi durumda korunagelmiş 5., 6. ve 7. kemerler ise yıkılmıştır.

Aquaeductus'un kemerli bölümünde bulunan dikmelerden güneyden kuzeye doğru onuncu sırada yer alanın (AQ 10) güney kısmı 82. cm'den sonra batıya doğru kırılarak 22 derecelik bir sapmayla iki farklı yönde inşa edilmiştir (Fig. 9). Böylelikle sular kent merkezinde, muhtemelen agoranın batısında bulunduğu düşünülen castellum aquae'ye yönlendirilmiş olmalıdır.

AQ 10 numaralı kemer ayağından itibaren kuzeye doğru 6 adet dikme ve üzerlerine yerleştirilmiş 6 adet kemer bulunmaktadır. Bunlardan 13 ve 14 numaralı dik-

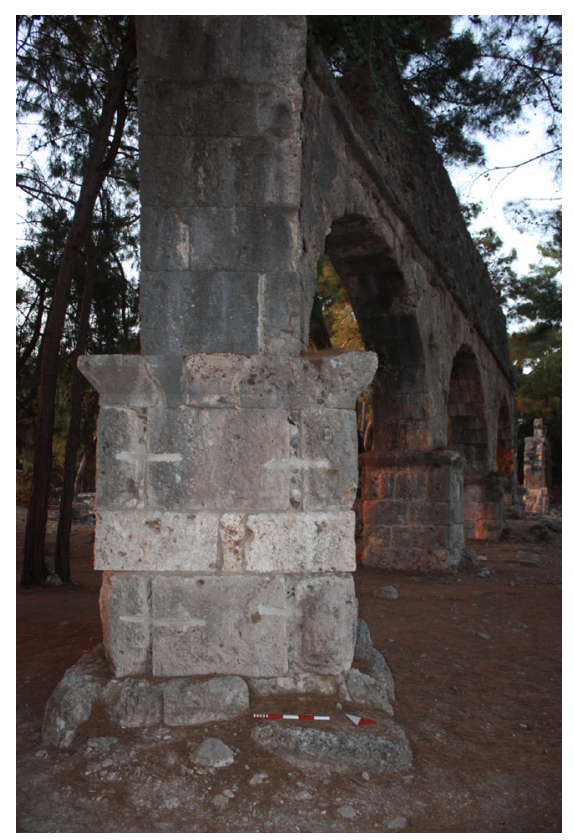

Fig. 9. AQ 10, Aquaeductus 10 Numaralı Dikme meler arasındaki kemer yıkılmıştır. Suyoluna ait, gözlemlenebilen tüm dikmelerin boyutlarıyla kemer açıklıkları ölçülüp kayda geçirilmiştir. 
Suyolunun alt kısmı dikdörtgen bloklardan örülmüş üst tarafı ise 1,51 m yüksekliğinde ve 56 $\mathrm{cm}$ genişliğinde moloz taş ve harçla inşa edilmiştir. Yine üst bölümde, duvara bitişik $59 \mathrm{~cm}$ genişlikte bir alan düzenlenmiştir. Akdeniz havzasındaki diğer örneklerden bilindiği üzere suyollarının kontrolü ve bakımı için servis yolları bulunmaktaydı. Phaselis'teki bu alan da aynı amaçla tasarlanmış olmalıdır.

Ölçümler sonucunda kemerleri taşıyan dikmelerin uzunluklarının (kuzey-güney yönünde) 1,73 $\mathrm{m}$ ile 1,96 m arasında, genişliklerinin de (doğu-batı) 1,76 m ile 2,21 m arasında değiştiği hesaplanmıştır.

Güneyden kuzeye dikme ölçüleri sırasıyla; 1 . dikme: boy 1,8 m; en 1,8 m; 2 . dikme: boy 1,84 $\mathrm{m}$; en $1,8 \mathrm{~m}$; 3 . dikme: boy $1,8 \mathrm{~m}$; en 1,82 m; 4. dikme: boy $1,86 \mathrm{~m}$; en 1,85 m; 5 . dikme: boy $1,96 \mathrm{~m}$; en 1,88 m; 6 . dikme: boy 1,79 m; en 2,21 m; 7. dikme: boy 1,89 m; en 1,77 m; 8 . Dikme: boy $1,73 \mathrm{~m}$; en $1,77 \mathrm{~m}$; ve 9 . Dikme: boy $1,81 \mathrm{~m}$; en 1,76 m'dir.

Kemerler güney duvarından itibaren ele alındığında ilk dört sıradaki iyi durumda olup sırasıyla $6,46 \mathrm{~m}, 6,48 \mathrm{~m}, 6,56 \mathrm{~m}$ ve 6,48 m genişliğe sahiptirler. 4-5, 5-6 ve 6-7 numaralı dikmeler üzerinde yükselen kemerler yıkılmış durumda olup sırasıyla açıklıkları 6,33 m, 6,38 m ve 6,41 m'dir. 7 numaralı dikmeden çift açı 10 numaralı dikmeye kadar kemer aralıkları ise 6,62 m, 6,49 m ve 6,51 m'dir. 10 numaralı dikmenin batı kenarının güney bölümü uzunluğu $82 \mathrm{~cm}$, kuzey bölümü ise 1,51 m olup toplamda 2,33 m'dir. Doğu kenarı açının dış kısmını oluşturduğundan güneyde uzunluk 1,31 m, kuzeyde 1,78 m toplamda da 3,09 m olup güney ve kuzey kısa kenarları 1,84 m'dir. 10 numaralı dikmenin kuzeyinde 6 adet daha iyi durumda dikme bulunmaktadır. Bunların genişlikleri (doğu-batı) 1,7 m ile 1,79 m arasında uzunlukları (kuzey-güney) ise 1,74 m ile 1,86 m arasında değişmektedir. Ölçüleri ise 11 numaralı dikme: boy 1,78 m; en 1,78 m; 12. dikme: boy 1,74 m; en 1,7 m; 13. dikme: boy 1,86 m; en 1,76 m; 14. dikme: boy 1,78 m; en 1,72 m; 15 . dikme: boy $1,76 \mathrm{~m}$; en 1,79 m; ve 16. dikme: boy 1,79 m; en 1,75 m'dir.

Bu dikmeler arasında kemer açıklıkları sırasıyla 6,19 m, 6,63 m, 6,61 m, 6,53 m (yıkık olan kemer), 6,51 m ve sonuncu kemerin ise 6,4 m'dir.

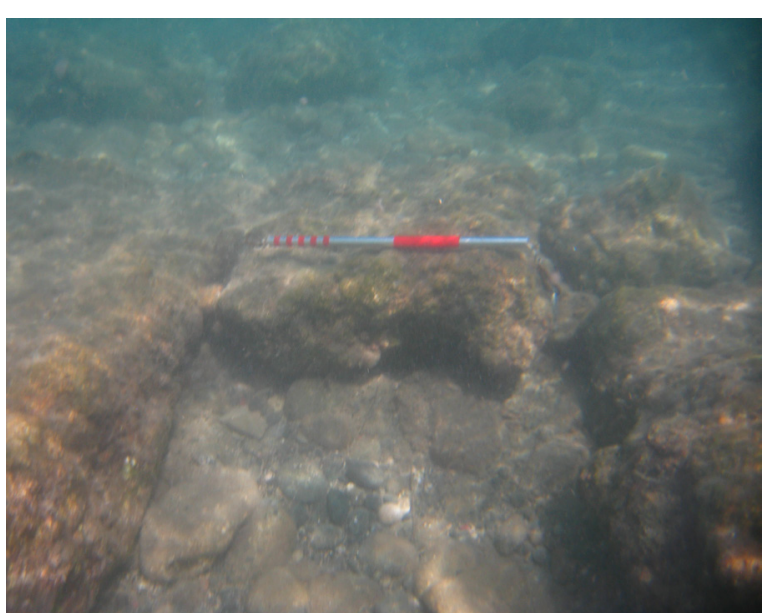

Fig. 10. AQ 29 Suyolunun Denizde Kalan Bölümü

\section{Suyolunun Denizde Kalan Bölümünü Tespit Çalışmaları (Fig. 10)}

Tektonik hareketler sonrasında deniz seviyesinde ortaya çıkan değişimler bilinmektedir. Bunun sonucunda suyolunun bir bölümü sular altında kalmış, karada kalan bir bölümü de zaman içerisinde tahribata uğrayıp neredeyse tamamen yıkılıp kaybolmuştur. Yukarıda belirttiğimiz ölçüm ve hesaplamalar kullanılarak gerçekleştirilen çalışmalarla aquaeductus'un denizde kalan ve yıkılan bölümünün belirlenmesi amaçlanmıştır. Bu araştırmalar kapsamında öncelikle kemer ayaklarından kalıntıları hala görülebilir olanlar tespit edilerek sonrasında daha kötü durumda bulunan diğer dikmelerin yerleri belirlenmeye çalışıımıştır. Illk tespitler sonrasında karada ve denizde yapılan ölçüm sonuçları ve hesaplamalarla daha kötü durumda bulunan diğer dikmelerin de yerleri tespit edilebilmiştir. 
En kuzeydeki 16 numaralı dikmeden günümüzde gölün denizle bağlantısını sağlayan kanala kadar uzanan boşlukta 3 adet daha dikme olduğu tespit edilmiştir. Bunlardan ilk ikisi (17 ve 18 numaralı dikmeler) kesin ve net olarak görülebilirken sonuncusu (19 numaralı) çakıllarla kaplı olup sadece zeminde dikdörtgen bloklar seçilebilmektedir. Hesaplamalar sonrasında yeri belirlenen 20 numaralı dikmenin olması gereken yerde herhangi bir iz bulunmamaktadır. Diğerleri kolayca saptanabilirken burada herhangi bir kalıntıya rastlanmaması önceki yıllarda gerçekleştirilen kanal çalışmaları (inşaatı) esnasında yıkılmış olabileceği düşüncesine yol açmaktadır. Illeride yapılacak sondajlar sonrasında yeraltında kalan temel kısmına ulaşılabilmesi mümkündür. KanaIın kuzeyindeki 21 ve 22 numaralı dikmelerin kalıntıları yine zemin seviyesinde seçilebilmekteyken 23 numaralı dikmenin tüm zemin blokları in-situ olarak tespit edilmiştir. Etrafında bir sıra daha bloklar bulunan bu dikmenin ölçüleri de boy 1,8 m, en 1,72 m olarak hesaplanmıştır. Yine gözlemler sonucu 24 numaralı dikmenin aquaeductus'un deniz üzerinde kalan son kemer ayağı olduğu saptanmıştır. Deniz içerisinde bulunan 25 numaralı dikmeyle arasındaki açıklık 6,42 m'dir. Karada ölçülen kemer aralıkları temel alınıp deniz içerisinde devam edilen araştırmalarda 25 numaralı dikmenin yeri kesin olarak belirlenebilmiştir. Deniz zemininin büyük çakıl taşları ile kaplı olması sonucu sadece üç adet dikmenin yeri dikdörtgen bloklarla birlikte kesin olarak saptanabilmiştir. Diğerleriyle aralarındaki mesafeler göz önünde bulundurulduğunda bunların sırasıyla 29, 30 (Fig. 11) ve 32 numaralı dikmeler olması gerektiği düşünülmektedir. 32 numaralı dikme deniz içerisinde bulunan son dikme olmalıdır. Suyun dışında (kuzeyde), deniz ile suyolunun bulunduğu yamaç arasında uzanan sahil bandında herhangi bir dikme izine rastlanmamıştır.

Araştırma sonrasında Phaselis suyoluna ait olduğu belirlenen buluntuların ölçüm ve belgeleme işlemleri tamamlanmıştır. Denizde yürütülen çalışmalar esnasında iki adet lahit ile üzerinde yazıt olması muhtemel bir adet de stel bulunmuştur.

Suyolunun Phaselis kenti içerisinde kemerler üzerinde ilerlemesinin nedeni, yüksekliği ve eğimi koruyarak suyun dağıtımı için gerekli basıncı sağlamaktır. Aquaeductus, kaynaktan castellum divisorium'a kadar olan güzergâhı kapsadığından bundan sonrası artık dağııım konusuna girmektedir. Suyun kente vardığı sektörde, içerisinde dağııımı düzenleyen vanalar barındıran bir su kulesi, su dağııım yapısı inşa edilirdi ${ }^{46}$. Bu yapı kent içerisindeki çeşmelere, hamamlara ve ayrıcalıklı kişilerin evlerine suyu dağıtmaya uygun olacak şekilde gerçekleştirilirdi. Evlerine su bağlanmasını dileyen kent sakinlerinin ödedikleri bedeller aquaeductus'ların bakımlarına harcanırdı.

\section{Akropolis'te Bulunan Hidrolik Strüktürle- rin Araştırılıp Kayıt Altına Alınması}

Yoğun yerleşim izleri barındıran akropolis'te Phaselislilerin, su ihtiyaçlarını karşılamak amacıyla inşa ettikleri strüktürlerin bulunmasına yönelik incelemeler 2015 Phaselis hid-

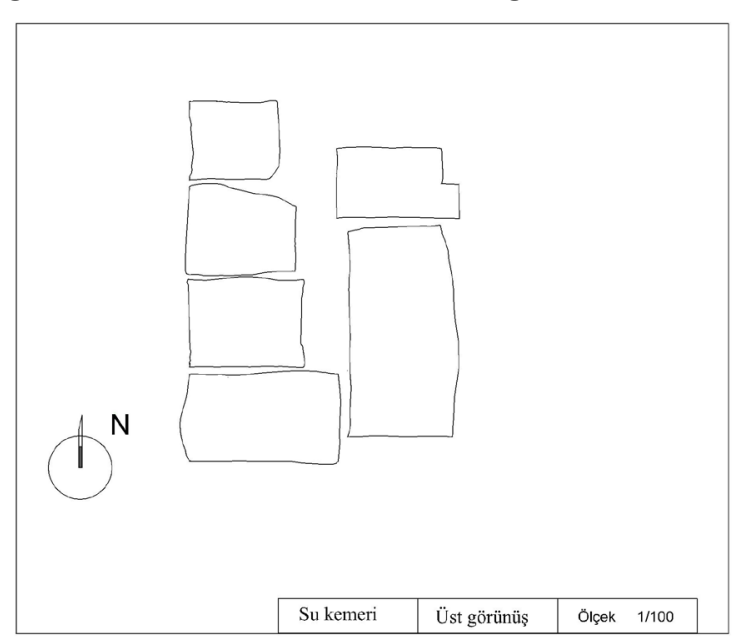

Fig. 11. AQ 30 Suyolunun Denizde Kalan Bölümü (Çizim: M. Çelik)

46 Vitr. de Arch. VIII. 7. 2. Bu yapılardan Nimes ve Pompeii kentlerinde bulunanlar günümüze değin iyi durumda koruna gelmiş ve birçok çalışmaya konu olmuşlardır. 
rografya çalışmalarının son bölümünü oluşturmaktadır.

Araştırmalara yarımadanın kuzeybatısında uzanan sektörden başlanmıştır. Tiyatro ile orta liman arasındaki yamaçta bulunan patika ile ulaşılabilen alanda gerçekleştirilen arazi çalışması sonrasında farklı formlarda sarnıçlar belirlenmiştir. Akropolis'in kuzeyinde toplam 1 hafta olarak planladığımız çalışmalar gerek buluntuların yoğunluğu gerekse çalışma şartlarının zorluğu (bitki örtüsü, sarnıç içerisindeki yılanlar vs.) sebebiyle toplam 12 gün sürmüştür. Bu süre içerisinde akropolis'te 27 adet sarnıç belgelenmiş büyük çoğunluğunun koordinatları hesaplanarak kayda geçirilmiştir. Farklı tip ve kapasitedeki sarnıçların tamamının duvarları pembemsi renkte hidrolik bir sıvayla kaplıdır. Dini yapılarla ilişkili olan sarnıçların, evlerde kullanılmak üzere inşa edilenlerden depolama kapasiteleri ve silindiriğe yakın formlarıyla ayrıştıkları görülür.

Akropolis'te bulunan hidrolik strüktürlerin belgeleme işlemleri sonrasında akropolis tepesinin doğal nedenlerle yıkılan batı bölümünde kesitleri görülen sarnıçların belgelenmesi planlanmıştır. Söz konusu sarnıçların ölçüm işlemleri bugün için eldeki imkânlarla mümkün olmadığından ve olası kazalara mahal vermemek amacıyla sadece deniz tarafından yarımadanın belgeleme (fotoğraf) işlemleri küçük bir tekne kullanılarak gerçekleştirilmiştir. Deniz içerisindeki yüzeye yakın kayalıklar risk teşkil ettiğinden kimi sarnıçların görüntüsü uzaktan alınmıştır.

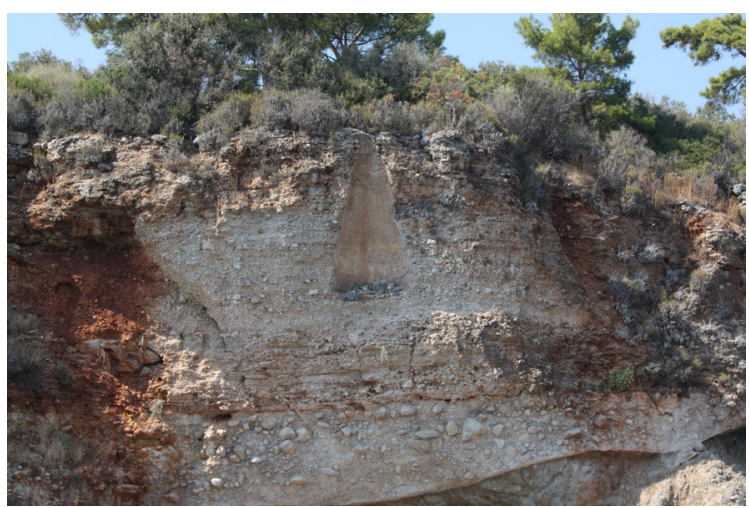

Fig. 12. Akropolis'teki Yıkık Sarnıçlara Bir Örnek

Akropolis yerleşmesinin yer aldığı yarımadanın batı kenarındaki yıkık sarnıç sayısı günümüz itibarıyla 8 adettir. Sarnıçların durumu kesit imkânı sunduğundan (Fig. 12) sarnıç tipolojisi belirlenmesinde ve sınıflandırmada büyük faydalar sağlamaktadırlar.

2015 yılı Phaselis su sistemleri ve hidrografya araştırmalarının akropolisi kapsayan bölümünde önceki yıllarda bulunanlarla birlikte sayıları otuzu aşan sarnıçlar başka bir çalışma içerisinde detaylıca ele alınacaktır.

\section{Değerlendirme}

Tahtalı Dağı doğu yamacındaki kaynakların suları, arazinin eğimine göre seçilen bir yerde inşa edilen rezervuara kazayağı formunda yerleştirilen kanallarla taşınmış, buradan da kente iletilmiş olmalıdır. Gerek duyulduğunda, suyolunun geçtiği güzergâhta ana kaynaktan daha aşağı kesimlere ikincil kaynaklardan gelen suları toplamaya yarayan ve aynı zamanda çökeltme havuzu işlevi gören yapılar ilave edilmiştir. Böylelikle suların akış hızı azaltıldığı gibi aynı zamanda suyun içerisinde bulunan kireç ve olası tortudan kısmen de olsa arındırılması sağlanmıştır ${ }^{47}$.

Tahtalı Dağı doğu yamacında saptanan kaynakların sularının kente ulaştırılmaları, membaların konumları ve coğrafi şartlar nedeniyle karmaşık bir sorun olarak karşımıza çıkmaktadır. Romalı mühendislerin benzer durumlarda suyun akış şiddetini azaltmak ve aquaeductus'u oluşturan mimari elemanlara zarar vermesini önlemek için uyguladıkları teknikler değerlendirildiğinde suyun Phaselis'e götürülme şekli konusunda karşımıza üç farklı alternatif çıkmaktadır:

1. Suyolunun güzergâhını uzatmak

47 Duval 1989, 1100. 
2. Düşü ve sakinleştirme havuzları, kanal içerisinde basamaklı enerji kırıcılar ve enerji kırma kuyuları kullanarak eğimin doğurabileceği akış hızını düşürmek.

3. Her iki tekniği birlikte kullanmak.

Bugüne kadar Phaselis ve territoryumunda gerçekleştirilen araştırmalarda suyolunun güzergâhı henüz kesinlik kazanmamıştır. İncelenen yoğun bitki örtüsüyle kaplı yamaçlarda yüzlerce teras duvarına rastlanmıştır. Bu düzenlemelerin tarıma elverişli alanlar yaratmaya yönelik olduğu şüphesizdir. Suyolu güzergâhının geçtiği tahmin edilen alanlarda rastlanan kırık pişmiş toprak boru parçalarının, aquaeductus'tan bu alanlara, atölyelere ve çiftlik yerleşimlerine su sağlamaya yönelik düzenlenen kanallara ait olabileceği göz ardı edilmemelidir. Gelecek dönemlerde araştırma alanının genişletilerek Tahtalı Dağı'ndan aşağıya inen dere yataklarının belirlenmesi ve vadilerle birlikte taranması, Phaselis suyolu hakkındaki bilgi eksikliğinin giderilmesine büyük katkılar sağlayacaktır.

Sonuç olarak, 2015 yılı Phaselis kenti suyolları ve hidrolik düzenlemeleri araştırmaları sonuçları Akdeniz havzasında bilinen diğer örneklerle karşılaştırılıp değerlendirdiğinde, daha önceki çaıışmalarda savlananların tersine, Tahtalı Dağı doğu yamacı pınarlarından elde edilen suların kente düz bir hat şeklinde iletildiğini söylemenin mümkün olmadığını ortaya çıkarmaktadır. 


\section{BİBLIYOGRAFYA}

\section{Antik Kaynaklar}

Frontin. strat.

Plin. nat.

Vitr. de Arch.

\section{Modern Literatür}

Arslan - Tüner Önen 2015

Bonnin 1984

Bourgeois 1992

Burdy - Taşlıalan 1997

Burdy 2002

Burdy - Audin 1979

Chanson 2000

Chanson 2001

Chanson 2002

Büyükyıldırım 1994

Fabre et al. 2005

Duval 1989

de Montauzan 1897

Léger 1875

Garbrecht 1979

Grenier 1960

Güldalı et al.1991
(= Sextus Iulius Frontinus, Strategematon)

Kullanılan Metin ve Çeviri: The Strategems and the Aqueducts of Rome. Trans. C. E. Ennett. London - New York 1925 (The Loeb Classical Library).

(= G. Plinius Secundus "Yaşıı", Naturalis Historia)

Kullanılan Metin ve Çeviri: Pliny, Natural History, vols. I-X. Trans. H. R. Rackham, W. H. S. Jones - D. E. Eichholz. Cambridge, Massachusetts London 1938-1971 (The Loeb Classical Library).

(= Vitruvius, De Architectura)

Kullanılan Metin ve Çeviriler: On Architecture, vols. I-II. Trans. F. Granger. London - New York 1931-1934 (The Loeb Classical Library).

Vitruvius, Mimarlık Üzerine On Kitap. Çev. S. Güven. İstanbul 1998³.

M. Arslan - N. Tüner Önen, "Phaselis ve Teritoryumu Yüzey Araştırması 2014". Anmed: Anadolu Akdenizi Arkeoloji Haberleri 2015/13 (2015) 198207.

J. Bonnin, L'eau dans l'Antiquité, L'hydraulique Avant Notre Ere. Paris 1984.

C. Bourgeois, Monuments et Sanctuaires du Culte Gallo-Romain de l'eau. Paris 1992.

J. Burdy - M. Taşlıalan, "L'aqueduc d'Antioche de Pisidie". Anatolia Antiqua 5 (1997) 133-166.

J. Burdy, Les Aqueducs Romains de Lyon. Lyon 2002.

J. Burdy - A. Audin, "Les Quatre Aqueducs de Lyon Capitale des Gaules". Dossier de l'Archéologie 38 (1979) 52-61.

H. Chanson, "Hydraulics of Roman Aqueducts: Steep Chutes, Cascades, and Dropshafts". AJA 104/1 (2000) 47-72.

H. Chanson, The Hydrallics of Stepped Chutes and Spillways. Lisse 2001.

H. Chanson, "Certains Aspects de la Conception Hydraulique des Aqueducs Romains, Some Aspects of the Hydraulic Design of Roman Aqueducts". La Houille Blanche 6/7 (2002) 43-58.

G. Büyükyıldırım, Antalya Bölgesi Tarihi Su Yapıları. Ankara 1994.

G. Fabre, J.-L. Fiches - P. Leveau, "Recherches Récentes sur les Aqueducs Romains de Gaule Méditerranéenne". Gallia 62 (2005) 5-12.

P. M. Duval, "Réflexion sur les Aqueducs Romains, à propos du Pont du Gard". Ed. Anonymous, Travaux sur la Gaule (1946-1986). Rome (1989) 1097-1108.

C. G. de Montauzan, Les Aqueduc de Lyon. Paris 1897.

A. Léger, Travaux Publics au temps des Romains. Paris 1875.

G. Garbrecht, "L'alimentation en eau d'une ville Grecque: Pergame". Dossier de l'Archéologie 38 (1979) 26-33.

A. Grenier, Manuel d'archéologie Gallo-Romaine: Les Monuments des eaux. Paris 1960.

N. Güldalı, L. Nazik, K. Tüfekçi, C. Soylu, B. Aksoy, S. Beydeş - C. Acar, Kemer-Elmalı-Kalkan Arasında Doğal Mağaralar. MTA Raporu. Ankara 1991. 
Harfouche et al. 2005

Del Cura 2001

Hodges 2000

Kessener 2000

Lassale 1979

Leveau 1976

Leveau 1979

Liot 1963

Litaudon 2004

Rouse - Ince 1957

Schäfer 1981

Tüner Önen 2008

Tüner Önen - Akçay 2014
R. Harfouche, C. Sanchez - P. Poupet, "Aménagements Hydrauliques et Paysage Rurql de Narbonnaise a Mailhac". Gallia 62 (2005) 119-130.

M. H. Del Cura, "El Abastecimiento de Aguas Romano a Tiermes". Obra Publica III (2001) 26-33.

A. T. Hodges, "Aqueducts". Ed. O. Wikander, Handbook of Ancient Water Technology. Leiden, Boston - Köln (2000) 39-65.

P. Kessener, "The Aqueduct at Aspendos and its Inverted Siphon". Journal of Roman Archaeology 13 (2000) 104-132.

V. Lassale, "Le Pont du Gard et l'aqueduc de Nimes". Dossier de I'Archéologie 38 (1979) 62-73.

P. Leveau, L'alimentation en eau de la Mauritanie et l'aqueduc de Cherchell. Paris 1976.

P. Leveau, "Les Techniques de Construction des Aqueducs". Dossier de I'Archéologie 38 (1979) 8-19.

C. Liot, "Contribution à l'étude des Aqueducs Romains en Touraine. Recherches sur l'alimentation en eau de Caesarodunum à l'époque Romaine par l'aqueduc de Fontenay". Revue Archéologique du Centre de la France II/4 (1963) 293-310.

J. C. Litaudon, "Les Aqueducs Antiques. Conduire l'eau (Aquae Ductus)". Eds. R. Alba, I. Moreno - R. G. Martínez, Elementos de Ingeniería Romana, Congreso Europeo "Las Obras Públicas Romanas". Tarragona (2004) 7186

H. Rouse - S. Ince, History of Hydraulics. lowa 1957.

J. Schäfer, Phaselis. Beiträge zur Topographie und Geschichte der Stadt und ihrer Häfen. Tübingen 1981.

N. Tüner-Önen, Phaselis Antik Kenti ve Teritoryumu. Yayınlanmamış Doktora Tezi, Akdeniz Üniversitesi. Antalya 2008.

N. Tüner Önen - A. Akçay, "Phaselis Kentinin Su Teminine İlişkin Gözlemler ve Dijital Epigrafi Çalışmaları”. MJH IV/2 (2014) 279-292. 